\title{
Long-term changes and distribution of mercury concentrations in surface sediments of the Gdansk Basin (Southern Baltic Sea)
}

\author{
Agnieszka Jędruch $^{1}$ - Jacek Beldowski ${ }^{2}$. Magdalena Beldowska ${ }^{1}$
}

Received: 13 October 2014 / Accepted: 4 May 2015 /Published online: 16 May 2015

(C) The Author(s) 2015. This article is published with open access at Springerlink.com

\begin{abstract}
Purpose In the Baltic Sea, the reduction of mercury load is estimated to be $44 \%$ compared to the end of the previous century. Confirmation of mercury load decrease is frequently based on sedimentary mercury profiles. This study aims to assess the inter-annual changes of mercury concentration and the net input in surface sediments, in order to assess the effect of decreased emissions and other processes.

Materials and methods Surface sediments were collected in 2011-2013 from areas where existing data series were available. Sediments were freeze dried, and total mercury concentrations, loss on ignition and fine fraction content were analysed. We compared recent concentrations of mercury in the coastal zone of the Baltic Sea to values previously reported in the same area since 1993. Net mercury deposition in the analysed sediments and previously reported data were calculated. The observed variability was correlated to climaterelated processes and input changes.

Results and discussion Three studied areas - major river mouth, shallow bay and offshore area-were significantly different in terms of sediment type and mercury concentration. Total mercury concentrations in the study area in 2011-2013 ranged between 2 and $260 \mathrm{ng} \mathrm{g}^{-1}$ dry weight (dw) (mean $61 \mathrm{ng} \mathrm{g}^{-1} \mathrm{dw}$; median $36 \mathrm{ng} \mathrm{g}^{-1} \mathrm{dw}$ ). Nearly $75 \%$ of the obtained results did not exceed $50 \mathrm{ng} \mathrm{g}^{-1} \mathrm{dw}$, while concentrations $>200 \mathrm{ng} \mathrm{g}^{-1} \mathrm{dw}$ accounted for a little over $5 \%$ of all
\end{abstract}

Responsible editor: Carolyn Oldham

Jacek Bełdowski

hyron@iopan.gda.pl

Institute of Oceanography, University of Gdańsk, Gdańsk, Poland

2 Institute of Oceanology, Polish Academy of Sciences, 81-712 Sopot, Poland the obtained results. Mercury input calculated for the area was much smaller than that recorded for the 1990s, but was characterised with large inter-annual variability, attributed to climate-related processes.

Conclusions Although a decreasing trend could be observed, it is modified by inter-annual variability. It follows from observations that in the present situation, where mercury emission has been successfully inhibited, that concentrations of this metal in sediments reflect natural metal migration processes rather than the direct influence of anthropogenic sources.

Keywords Baltic Sea $\cdot$ Long-term changes $\cdot$ Mercury $\cdot$ Net input $\cdot$ Surface sediments

\section{Introduction}

The Baltic Sea is an inland sea with a limited water exchange with the North Sea, which explains why the main sources of mercury in this sea are rivers, transporting pollutants from the drainage area, and atmospheric deposition. Owing to the high toxicity of mercury and the fact that its primary source for humans is fish/seafood (Jackson 1998; Boening 2000), a number of initiatives have been undertaken with a view to reducing the emission of this metal into the Baltic. As a result of these, the metal load has dropped by $44 \%$ since the $1990 \mathrm{~s}$ (HELCOM 2010).

Mercury, like other heavy metals that reach the surface water of the Baltic, is deposited on seabed sediments. The Baltic Sea, being a basin with a limited water exchange, surrounded by industrialised areas, is characterised by a significant enrichment of the surface layers of the sediment with mercury and other trace metals (Beldowski and Pempkowiak 2009; Uścinowicz et al. 2011). Seabed sediments were once 
considered to be the ultimate deposition site for mercury, which does not pose an environmental threat when in the stable $\mathrm{HgS}$ form (WHO 1990). However, as a result of a series of biotic and abiotic processes, the metal can become remobilised from the sediment surface (Bełdowski and Pempkowiak 2007, 2009; Bełdowski et al. 2009). The mercury released into pore water and near-bottom water can become accumulated in benthic organisms and biomagnified in subsequent links of the trophic chain, posing the greatest threat to marine mammals, aquatic birds and humans (Jackson 1998). Mercury released from sediments into water through its transformation into the gaseous form can also be emitted into the air, which is of particular importance in the mercury budget in coastal areas (Bełdowska et al. 2008).

In the coastal zone, fine-grained material is relocated as a result of wind mixing and can adsorb mercury released into the water column and be transported, through a cycle of multiple phases of sedimentation and resuspension, into areas where sediments are accumulated (Christiansen et al. 2002; Emeis et al. 2002).

In the second half of the twentieth century, concentrations of trace metals in sediments were normally associated with the occurrence of potent local sources of this metal. Now that mercury emission has been considerably limited, the level of mercury concentration in surface sediments is determined not only by human activity but also by the increasing influence of biogeochemical processes. The transformations of mercury in bottom sediments remain in a delicate balance. One of the main transformations is an early diagenesis of organic matter, resulting in fulvic acids turning into humic acids and then into the insoluble humins (Pempkowiak 1997). Another one is the reduction of sulphates into sulphides (Pempkowiak 1997) under the anaerobic conditions which are present in deeper layers of sediment. The mercury bound to these sediment fractions becomes stabilised, either in the insoluble humins or in the form of mercury sulphide (Jackson 1998). These transformations, however, can be reversed, depending on environmental conditions, during the decomposition of labile organic matter or the oxidation of mercury sulphides and other metals to sulphates, and the mercury contained within them can be released into pore water (Wallschläger et al. 1998; Beldowski and Pempkowiak 2009). The environmental conditions which control processes in seabed sediments are, among others, temperature, inflow of organic matter or oxygen concentration in the near-bottom water; their values are hence directly connected to climate changes in the Baltic Sea region. Because of this, a hypothesis has been formulated that the mercury concentration changes in the surface layer of the sediments in the Gdansk Basin are only partially related to the limited emission of this metal into the environment. Significant factors influencing their variability are the processes of metal exchange taking place in the near-bottom zone, as well as episodes of extreme natural phenomena introducing sizeable mercury loads into the basin over a short time period.

\section{Materials and methods}

The research was carried out in the Gdansk Basin area, located in the south-eastern part of the Baltic Sea (Fig. 1). The basin in this area has an average depth of about $50 \mathrm{~m}$ and is shaped like a pan, regularly increasing in depth and reaching $118 \mathrm{~m}$ at the deepest area at the centre of the Gdansk Deep (Majewski 1990). The sediments of the Gdansk Basin are diverse in character and distribution, which is related mainly to the depth of the basin and the shape of the coast. In the shallow area of the Gdansk Basin, hydrodynamic processes make permanent deposition of fine-grained sediments impossible, and the prevailing sediment types are sand and gravelly sand. Medium and fine silts are usually found below the pycnocline (about $60 \mathrm{~m}$ ), covering wide areas of the bottom in the deep water area of the basin (Jankowska and Łęczyński 1993; Uścinowicz et al. 2011).

Sixteen test stations were set up in the Gdansk Basin region (Fig. 1). The study region was divided into three study areas: the centre of the Gulf of Gdansk, the Vistula River mouth and the Puck Bay. The test stations in the mouth of the Vistula (VM1, VM2, VM3 and VM4) are located where there is a direct flow of mercury originating on land. The Vistula is the second largest river (after the Neva) discharging into the Baltic Sea - the average multiannual discharge is $1081 \mathrm{~m}^{3} \mathrm{~s}^{-1}$. Its catchment area, stretching across $194,000 \mathrm{~km}^{2}$, accounts for $12 \%$ of the drainage area of the Baltic Sea (HELCOM

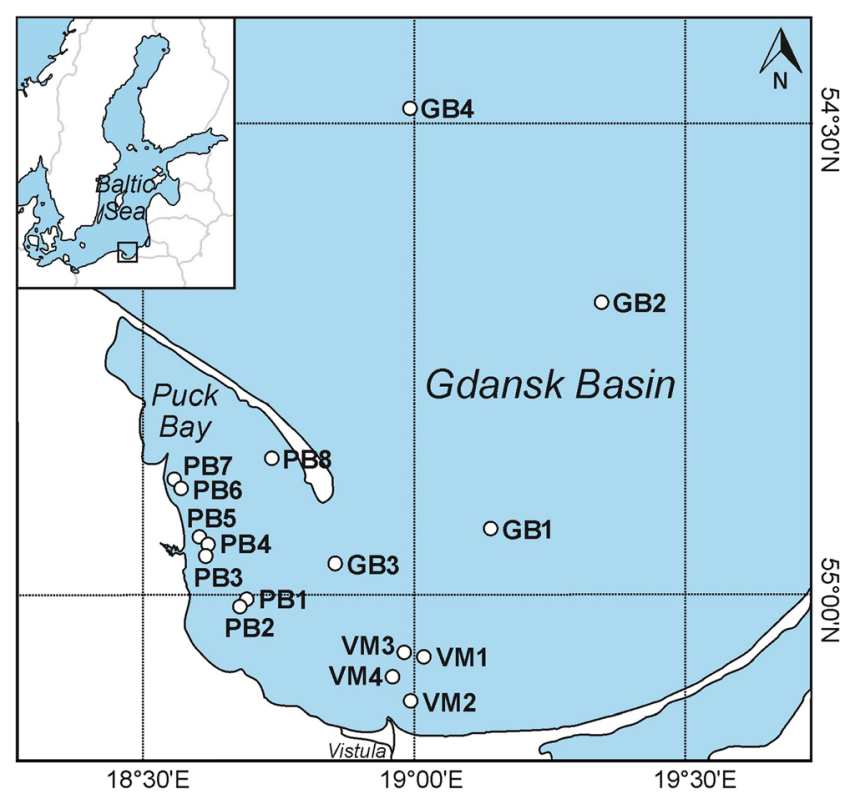

Fig. 1 Location of sampling sites. VM stations denote Vistula mouth Region, $P B$ stations represent the Puck Bay, while $G B$ stations are located in offshore Gdańsk Basin 
2004). Eight stations were placed in the region of the Puck Bay, which is relatively shallow (on average $15.5 \mathrm{~m}$ ) (Fig. 1) and where water exchange is vastly limited.

Several places located in this region are attractive for tourists: Gdynia (250,000 inhabitants), Rewa (900 inhabitants), Puck (11,500 inhabitants), Wladyslawowo (15,300 inhabitants), Chałupy (370 inhabitants), Jastarnia (4000 inhabitants) and Hel (3800 inhabitants). This region is visited every year by about two million tourists (GUS 2014). Sources of pollution in this region include a shipyard, a harbour, fishing ports and water purification plants, as well as rivers: the Reda $\left(5.5 \mathrm{~m}^{3} \mathrm{~s}^{-1}\right)$, the Zagorska Struga $\left(1.2 \mathrm{~m}^{3} \mathrm{~s}^{-1}\right)$, the Gizdepka $\left(0.2 \mathrm{~m}^{3} \mathrm{~s}^{-1}\right)$ and the Plutnica $\left(0.2 \mathrm{~m}^{3} \mathrm{~s}^{-1}\right)$ (Cyberski 1993). In terms of the air, electrical power and heat plants, where coal and coke are incinerated, together with numerous home hearths, represent a significant source of mercury.

Samples of surface sediments were collected between 2011 and 2013 in different seasons during 11 research trips on board the sail yacht Oceania and the hydrographic survey ship Oceanograf-2. In 2011, five trips were undertaken (in April, July, September, October and November), in 2012 there were four (in January, March, May and September), and the final two trips were in 2013 (in February and April). Samples of surface sediments were collected using a box corer without distorting the original stratification or structure of the sediments. The upper layer of the sediment, 1-cm thick, was taken for analysis, having been separated using a Teflon spatula. The sediments were placed in polyethylene Ziploc bags and preserved at a temperature of $-20^{\circ} \mathrm{C}$ until analysis.

Preparing samples for analysis involved lyophilizing the sedimentary material, and then homogenising it in a ball mill using an agate shell. Total mercury concentration $\left(\mathrm{Hg}_{\mathrm{TOT}}\right)$ in surface sediments was assayed using the atomic adsorption spectroscopy method, in an AMA245 mercury analyser (Plzen, Czech Republic) after thermal decomposition in pure oxygen. The quality check of the method involved repeating the analysis of the studied samples five times and analysing the certified reference material (GBW 07314-offshore marine sediment). The method had a high recovery level (98\%), while the relative standard deviation was no higher than $5 \%$. Limit of quantification was $0.005 \mathrm{ng} \mathrm{g}^{-1}$.

Additionally, subsamples of sediment were collected each time in order to determine its basic parameters-wetness, granulation and proportion of organic matter. The granulometric composition of the sediments was determined using sieve analysis. The size fractions were determined using Udden's classification (1914), as modified by Wentworth (1922). The proportion of organic matter in the sediment was determined using loss on ignition (LOI) at $550{ }^{\circ} \mathrm{C}$, accepted to be optimal for Baltic sediments (Ciborowski 2010).

The obtained results for $\mathrm{Hg}_{\text {TOT }}$ (ng g ${ }^{-1}$ dry weight (dw)) were also presented as values normalised in relation to the percentage of the fine-grained sediment fraction $(<0.063 \mathrm{~mm}$ in diameter; $\left.\operatorname{Hg} \varphi ; \mathrm{ng} \mathrm{g}^{-1}\right)$, and to the proportion of organic matter $\left(\mathrm{Hg}_{\mathrm{LOI}} ; \mathrm{ng} \mathrm{g}^{-1}\right)$ (Bełdowski and Pempkowiak 2007):

$\mathrm{Hg}_{\varphi}=\frac{\mathrm{Hg}_{\mathrm{TOT}}}{\%<0.063\left(10^{-2}\right)}$

$\mathrm{Hg}_{\mathrm{LOI}}=\frac{\mathrm{Hg}_{\mathrm{TOT}}}{\mathrm{LOI}\left(10^{-2}\right)}$

The net input of mercury into surface sediments was calculated using the following formula (Bełdowski et al. 2009):

$\Delta \mathrm{Hg}_{\mathrm{TOT}}=\frac{\omega}{10}\left(1-\frac{\mathrm{W}}{100}\right) \mathrm{d}_{\mathrm{s}} \mathrm{Hg}_{\mathrm{TOT}}$

where, $\Delta \mathrm{Hg}_{\mathrm{TOT}}$ is the mercury input into the sediment (ng year ${ }^{-1} \mathrm{~cm}^{2}$ ), $\omega$ is the sediment accumulation rate $\left(\mathrm{mm}\right.$ year $\left.{ }^{-1}\right), W$ is the sediment wetness (\%) and $d_{\mathrm{s}}$ is the sediment density $\left(\mathrm{g} \mathrm{cm}^{-3}\right)$.

Data concerning the rate of sediment accumulation in particular areas of the Gdansk Basin - the Vistula River mouth and the central part of the Gdansk Deep, estimated using the lead-210 dating method - were taken from studies conducted by Bełdowski and Pempkowiak (2007), Suplińska and Pietrzak-Flis (2008), Damrat et al. (2013) and Szmytkiewicz and Zalewska (2014). The density of the sediment used for the calculations was $2.55 \mathrm{~g} \mathrm{~cm}^{-3}$ for sandy sediments and $2.45 \mathrm{~g} \mathrm{~cm}^{-3}$ for sandy-silty sediments (Jankowska and Łęczyński 1993). The mean wetness of bottom sediments was assumed on the basis of data found in the literature.

Statistical analysis and graphic representation of the obtained results were conducted using the STATISTICA 10 programme by StatSoft. Owing to a limited number of samples, the analysed results were not characterised by a normal distribution (Shapiro-Wilk test, $p<0.05$ ). In order to determine the significance of the differences, the nonparametric KruskalWallis ANOVA test was used. Dependences between the analysed variables were determined on the basis of the Spearman correlation coefficient at a confidence interval of $95 \%$.

\section{Results and discussion}

Total mercury $\left(\mathrm{Hg}_{\text {Tот }}\right.$ ) concentrations in samples of surface sediments collected in the region of the Gdansk Basin in 2011-2013 ranged between 2 and $260 \mathrm{ng} \mathrm{g}^{-1} \mathrm{dw}$ (mean $61 \mathrm{ng} \mathrm{g}^{-1} \mathrm{dw}$; median $36 \mathrm{ng} \mathrm{g}^{-1} \mathrm{dw}$ ). Nearly $75 \%$ of the results did not exceed $50 \mathrm{ng} \mathrm{g}^{-1} \mathrm{dw}$, while concentrations $>200 \mathrm{ng} \mathrm{g}^{-1}$ $\mathrm{dw}$ accounted for a little over $5 \%$ of all the results (Fig. 2).

There were statistically significant differences between the concentrations of the metal between particular study areas: the centre of the Gulf of Gdansk, the Vistula River mouth and the Puck Bay (Kruskal-Wallis test, $p=0.006$ ). The spatial variability of $\mathrm{Hg}_{\text {тот }}$ concentrations in surface sediments in all studied 
Fig. 2 Statistical characteristics of total mercury concentrations in the sampling areas. Differences are significant at $p=0.06$

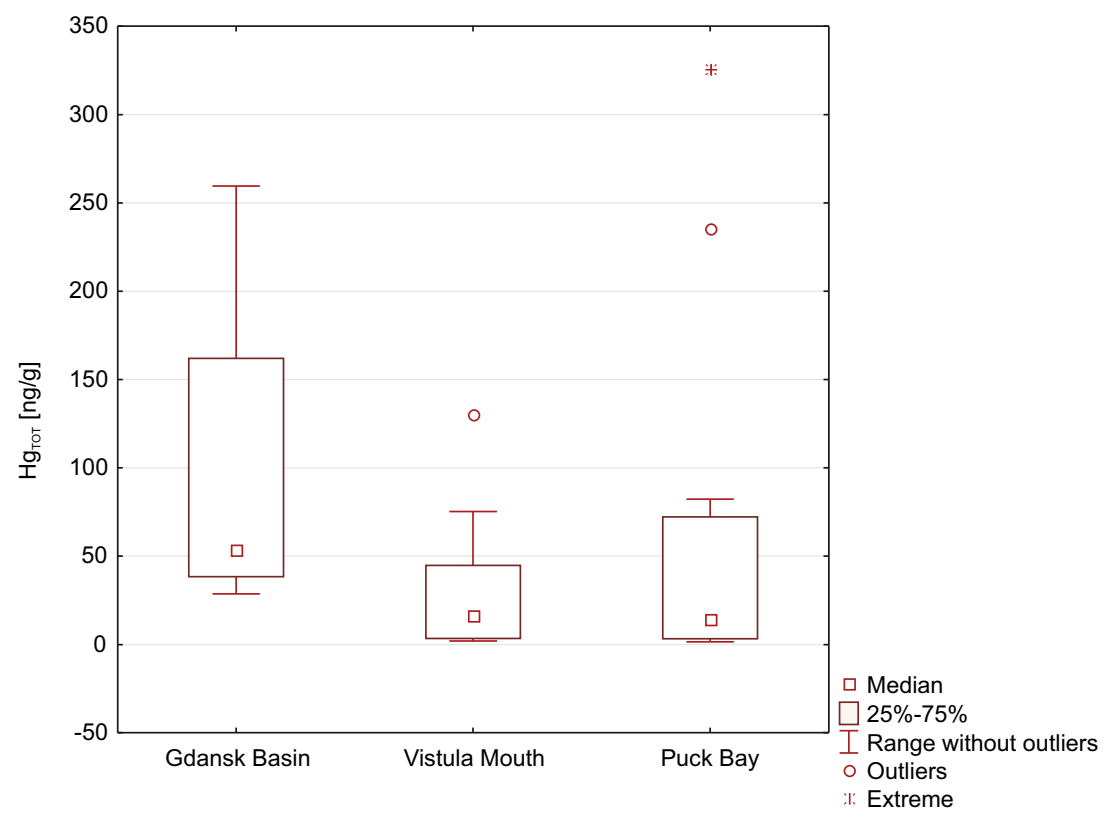

regions of the Baltic Sea was mainly related to the type of sediment found at a given station. Average grain size decreases with the distance from the coast-from the Puck Bay (medium sands) towards Vistula mouth (fine sands and coarse silts) and centre of the Gulf (fine silts). The fine-grained fraction and organic matter content in the sediment are among the most important factors determining the affinity of the sediment grains to metal ions. This is related mainly to the fact that the specific surface area of ultra-fine sediments is larger than that of sandy sediments, allowing for greater mercury adsorption. The enrichment of fine-grained particles with organic matter had a positive influence on their ability to bind and complex metals (Bełdowski and Pempkowiak 2007). This is confirmed by statistically significant correlations between metal concentration and the proportions of the sediment fraction $<0.063 \mathrm{~mm}$ in diameter $(R$ Spearman $=0.81, p=0.05)$ and organic matter content $(R$ Spearman $=0.79, p=0.05)$ (Table 1$)$.

Similar dependencies have also been observed in numerous studies both in the case of the Southern Baltic (e.g. Bełdowski

Table 1 Spearman correlation matrix of total mercury $\left(\mathrm{Hg}_{\mathrm{TOT}}\right)$ and other measured parameters in surface sediments of Gdańsk Basin in years 2012-2013

\begin{tabular}{llllll}
\hline & $\mathrm{Hg}_{\text {TOT }}$ & Depth & $\varphi<0.063 \mathrm{~mm}$ & LOI & $W$ \\
\hline $\mathrm{Hg}_{\text {TOT }}$ & 1 & & & & \\
Depth & 0.77 & 1 & & & \\
$\varphi<0.063 \mathrm{~mm}$ & 0.81 & 0.66 & 1 & 1 & \\
LOI & 0.79 & 0.76 & 0.84 & 0.80 & 1 \\
$W$ & 0.78 & 0.80 & 0.67 & & \\
\hline
\end{tabular}

$\mathrm{Hg}_{\text {TOт }}$ is the total mercury concentrations ( $\mathrm{ng} \mathrm{g}^{-1} \mathrm{dw}$ ), depth is the water depth (m), $\varphi<0.063 \mathrm{~mm}$ is the fine fraction content (\%), LOI is the loss on ignition (\%) and $W$ is the wetness of sediments (\%) and Pempkowiak 2007; Saniewska et al. 2010), and other basins of the world (e.g. Fitzgerald and Lamborg 2003; Hortellani et al. 2005; Lafabrie et al. 2011). It was also observed that the concentration of the metal increased with distance from the shore and hence the depth of the basin $(R$ Spearman $=0.77, p=0.05$ ) (Table 1). The depth of the basin had a significant influence on the conditions in the sedimentation environment, such as transportation and sediment material deposition. In the Baltic, higher mercury mobility was observed in shallow water sediments compared with areas of accumulation (Bełdowski et al. 2009). With increasing depth, and thus weakening of the dynamics of the environment, surface sediments were characterised by a greater proportion of the components responsible for the sorption of mercury.

\subsection{River Vistula mouth}

In the region of the River Vistula mouth, mercury concentrations in the surface sediments were much lower than in the central part of the Gulf of Gdansk; $\mathrm{Hg}_{\mathrm{TOT}}$ concentration medians in the sediments obtained for a set of tests for the particular stations ranged from $9 \mathrm{ng} \mathrm{g}^{-1} \mathrm{dw}$ (VM4) to $130 \mathrm{ng} \mathrm{g}^{-1}$ $\mathrm{dw}$ (VM3) and, as in the central part of the basin, did not show statistically significant differences for the particular stations (Kruskal-Wallis test, $p=0.11$ ) (Fig. 3a). The obtained values were comparable to concentrations found in this region in 1999-2002, which ranged from 6 to $111 \mathrm{ng} \mathrm{g}^{-1} \mathrm{dw}$ (Bełdowski and Pempkowiak 2007). Raised mercury values in 2010-2012 were caused by a flood on the Vistula in 2010, which was the largest flood in 160 years. At that time, more than a megagramme of mercury-polluted suspension was introduced into the Gulf of Gdansk with river water and was partly deposited in the area where the VM stations are located, 
Fig. 3 Statistical characteristics of $\mathbf{a}$ total mercury and $\mathbf{b}$ fine fraction normalised $(\operatorname{Hg} \Phi)$ and organic matter normalised $\left(\mathrm{Hg}_{\mathrm{LOI}}\right)$ mercury in the Vistula mouth region. Differences are significant at $p=0.06$ for $\mathrm{Hg}_{\text {TOT }}$, $p=0.2$ for $\mathrm{Hg}_{\mathrm{LOI}}$ and $p=0.1$ for $\operatorname{Hg} \Phi$
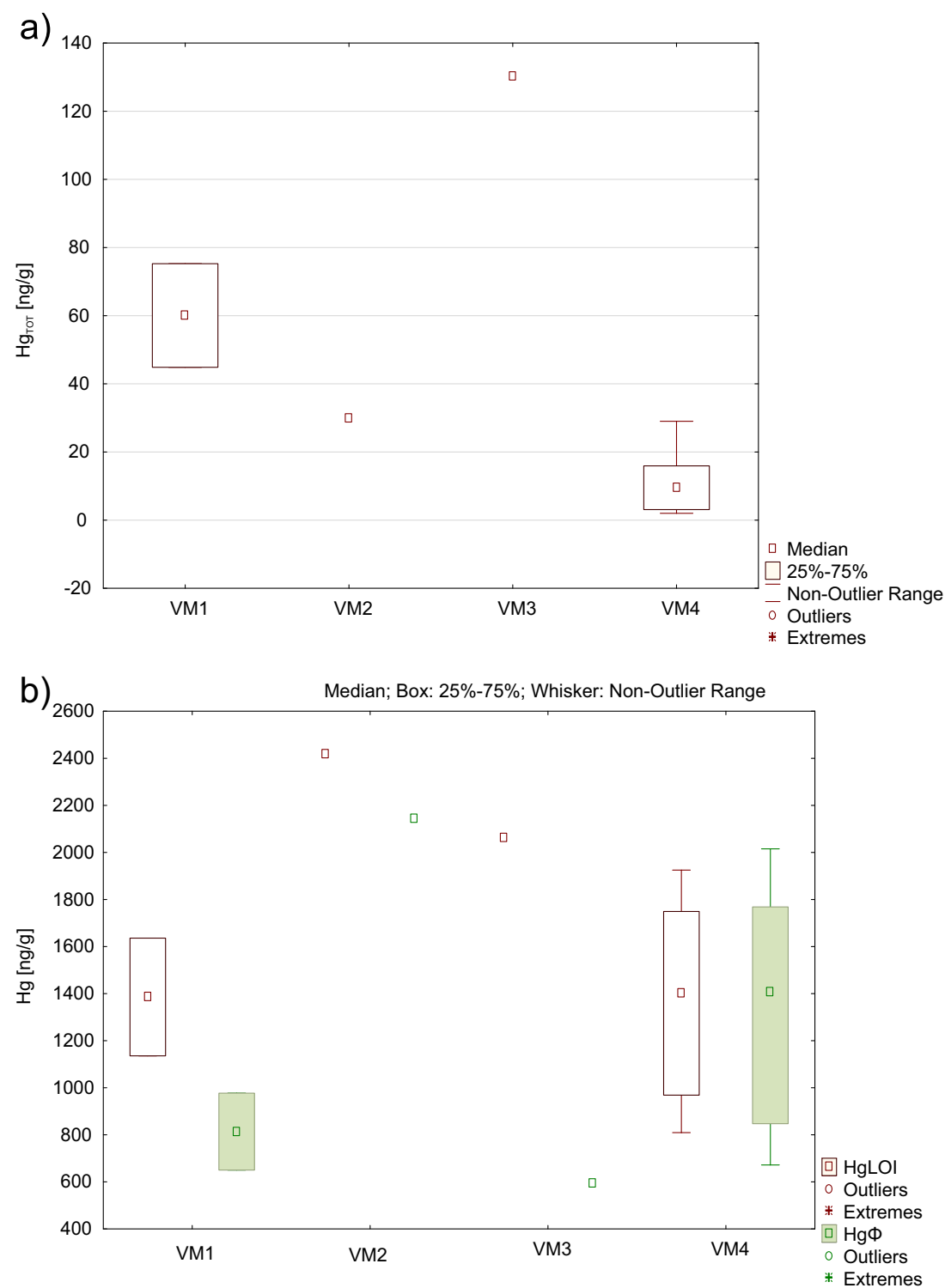

which could have resulted in raised metal concentrations in surface sediments (Zajaczkowski et al. 2010; Bełdowski et al. 2014; Saniewska et al. 2014). This phenomenon has been confirmed by studies conducted by Saniewska et al. (2014).

In sediments collected in the Vistula River mouth area, the sandy fraction prevailed. The proportion of grains $<0.063 \mathrm{~mm}$ in diameter in surface sediments at the stations in this area ranged from 0.1 to $22 \%$ (mean $4 \%$ ), while at the VM1, VM2 and VM4 stations it did not exceed $6 \%$ (mean $2 \%$ ); only in the area of station VM3 did it amount to $20 \%$ on average. The wetness of the sediments in this region ranged from 18 to $73 \%$ (mean $32 \%$ ), while organic matter content did not exceed $0.2-16 \%$ (mean $2 \%$ ).

The increase in the $\mathrm{Hg}_{\text {тот }}$ concentration in sediments located further away from the coast (VM3 and VM1) reflects the transportation of Vistula-borne material which is deposited in the area of undisturbed sedimentation (Pempkowiak et al.
2002; Bełdowski 2004). The concentrations of this metal, normalised to the content of the fine-grained sediment fraction $(\operatorname{Hg} \varphi)$, decreased with the distance from the river mouth (Fig. 3b), perhaps resulting from the fact that the river-borne, fine-grained material, rich in mercury, mixed with material with a lower pollutant content, thus becoming "diluted" (Bełdowski and Pempkowiak 2007). A similar tendency was observed in the case of $\mathrm{Hg}_{\mathrm{LO}}$ concentration, which indicates a drop in the proportion of mercury bound to organic matter as the distance from the river mouth increased. Mercury speciation analysis in surface sediments in the Vistula River mouth area confirms the drop in the proportion of mercury forms bound to organic substances, such as fulvic and humic acids, with a simultaneous increase in the proportion of the sulphide and residual fractions, as the distance from the river mouth increases (Bełdowski 2004). This may be related to, among other 
things, the labile mercury forms becoming remobilised into the water column (Wallschläger et al. 1998).

\subsection{Shallow Puck Bay}

Mercury concentrations in the sediments of the Puck Bay had the widest range of all the study areas, ranging from $2 \mathrm{ng} \mathrm{g}^{-1}$ $\mathrm{dw}$ (PB6 and PB7) to $45 \mathrm{ng} \mathrm{g}^{-1} \mathrm{dw}$ (PB5), while station PB8 was the only station where the values reached $325 \mathrm{ng} \mathrm{g}^{-1} \mathrm{dw}$ (mean $51 \mathrm{ng} \mathrm{g}^{-1} \mathrm{dw}$; median $14 \mathrm{ng} \mathrm{g}^{-1} \mathrm{dw}$ ). The variability of the metal concentrations within the test stations of the Puck Bay was not statistically relevant (Kruskal-Wallis test, $p=$ 0.27 ) (Fig. 4a). The values measured in the previous years ranged from 18 to $422 \mathrm{ng} \mathrm{g}^{-1} \mathrm{dw}$ (Boszke 1999; Bełdowski 2004; Bełdowski and Pempkowiak 2007; Uścinowicz et al. 2011). The decrease in mercury concentrations in the surface layer of the sediments in the basin compared to previous years may testify to an improvement in the condition of the environment, resulting from, among other factors, limited mercury emission from local sources. The reduction in sediment pollution of the Puck Bay may have been influenced by, for example, the modernisation and extension of the sewage treatment plant and the water supply and sewer system in the Pomeranian province. The extensive development of wind power farms in the coastal strip of the Puck Bay over the last decade could also have affected the reduction of metal emission into the environment.

The surface sediments collected in the Puck Bay region were sandy in character, and the proportion of grains $<0.063 \mathrm{~mm}$ ranged between 0.1 and $42 \%$ (mean $7 \%$ ). The wetness of surface sediments of the Puck Bay was 19-85\% (mean $39 \%$ ), while the proportion of organic matter in sediments was within the range of $0.3-17 \%$ (mean $5 \%$ ).
Fig. 4 Statistical characteristics of a total mercury and $\mathbf{b}$ fine fraction normalised $(\mathrm{Hg} \Phi)$ and organic matter normalised

$\left(\mathrm{Hg}_{\mathrm{LOI}}\right)$ mercury in the Puck Bay region. Differences are significant with $p=0.02$ for $\mathrm{Hg}_{\text {TОТ, }} p=0.2$ for $\mathrm{Hg}_{\mathrm{LOI}}$ and $p=0.08$ for $\mathrm{Hg} \Phi$
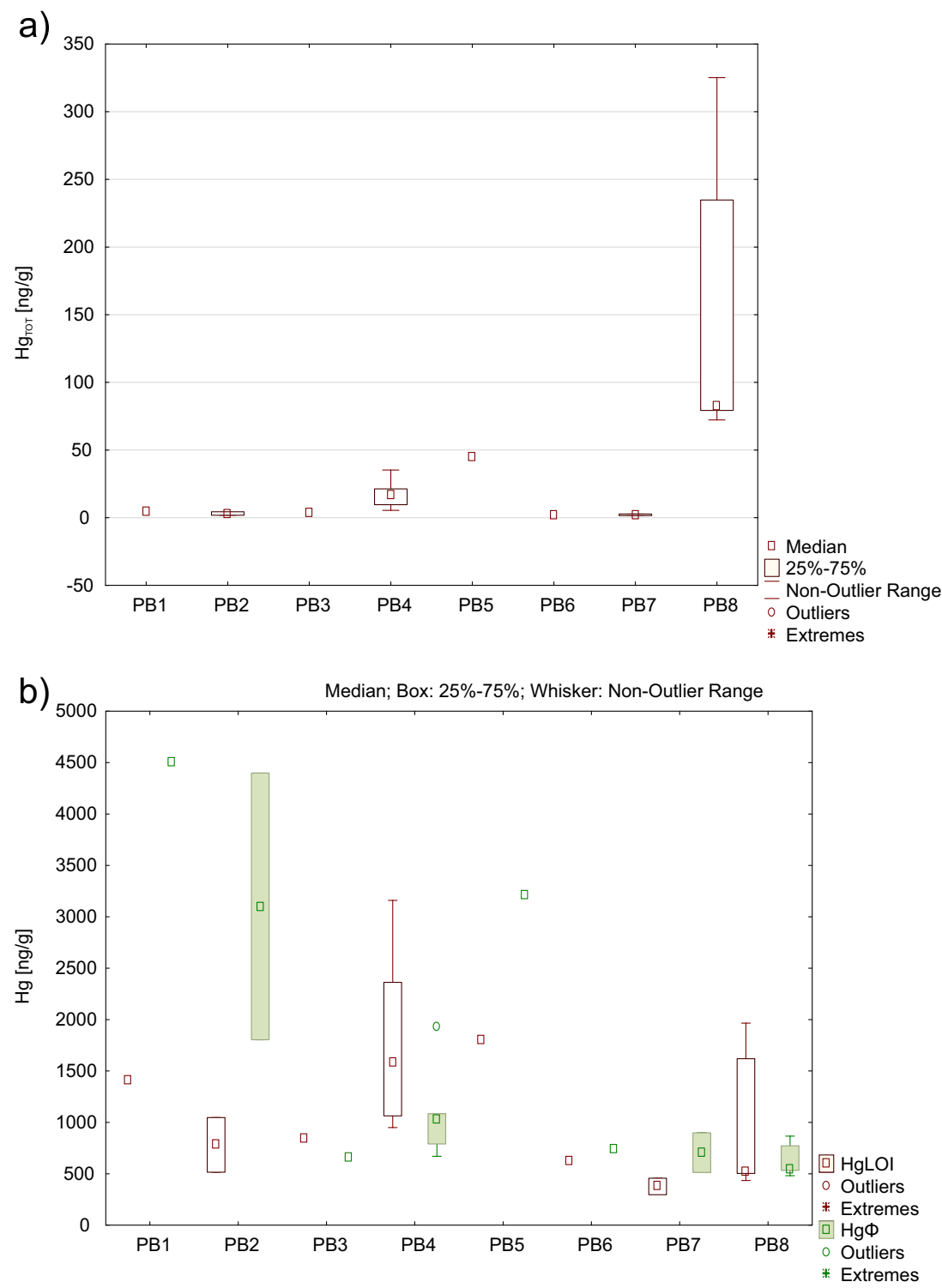
$\operatorname{Hg} \varphi$ concentrations that were distinctly higher than $\mathrm{Hg}_{\text {LOI }}$ (Fig. 4b) may testify to an input of inorganic mercury from anthropogenic sources (Daskalakis and O'Connor 1995). The results of metal speciation analyses in surface sediments of the coastal area of the basin point to a prevailing proportion of the sulphide and residual fractions (Bełdowski and Pempkowiak 2007). The shallow depth of the Puck Bay and thus the relatively good oxygen conditions make it impossible for these mercury forms to be formed in surface sediments - therefore, their presence suggests an inflow from the land (Jackson 1998; Bełdowski 2004). Anthropogenic influences become evident particularly in the areas of stations PB1, PB2 and PB5 where the concentration of mercury bound to the fine-grained fraction was found to be the highest among the studied stations (Fig. 4b) and at the same time much higher than the concentration normalised to the organic matter content.

\subsection{Area of accumulation-central part of the Gulf of Gdansk}

The highest mercury concentrations in the surface sediments of the Gdansk Basin were found in its central part (stations GB1, GB2, GB3 and GB4). The medians of $\mathrm{Hg}_{\text {Tот }}$ concentrations in sediments from a set of tests from particular stations ranged from 41.4 (GB1) to $134 \mathrm{ng} \mathrm{g}^{-1} \mathrm{dw}$ (GB4), while the values obtained at particular test stations were not characterised by statistically significant differences (KruskalWallis test, $p=0.54$ ) (Fig. 5a). These values were lower than those determined in the $1990 \mathrm{~s}$, which ranged from 2 to $680 \mathrm{ng} \mathrm{g}^{-1} \mathrm{dw}$ (Kannan and Falandysz 1998; Pempkowiak et al. 1998) and from data from the first decade of the twentyfirst century, which ranged from 74 to $240 \mathrm{ng} \mathrm{g}^{-1} \mathrm{dw}$ (Bełdowski and Pempkowiak 2003, 2007; Bełdowski 2004). The decrease in the concentration of the metal in this region is probably the result of a lower mercury emission and a consequential drop in mercury being deposited from the atmosphere
Fig. 5 Statistical characteristics of $\mathbf{a}$ total mercury and $\mathbf{b}$ fine fraction-normalised $(\operatorname{Hg} \Phi)$ and organic matter-normalised ( $\left.\mathrm{Hg}_{\mathrm{LOI}}\right)$ mercury in the Gdańsk Basin region. Differences are significant with $p=0.5$ for $\mathrm{Hg}_{\text {TOT }}$, $p=0.6$ for $\mathrm{Hg}_{\mathrm{LOI}}$ and $p=0.2$ for $\operatorname{Hg} \Phi$
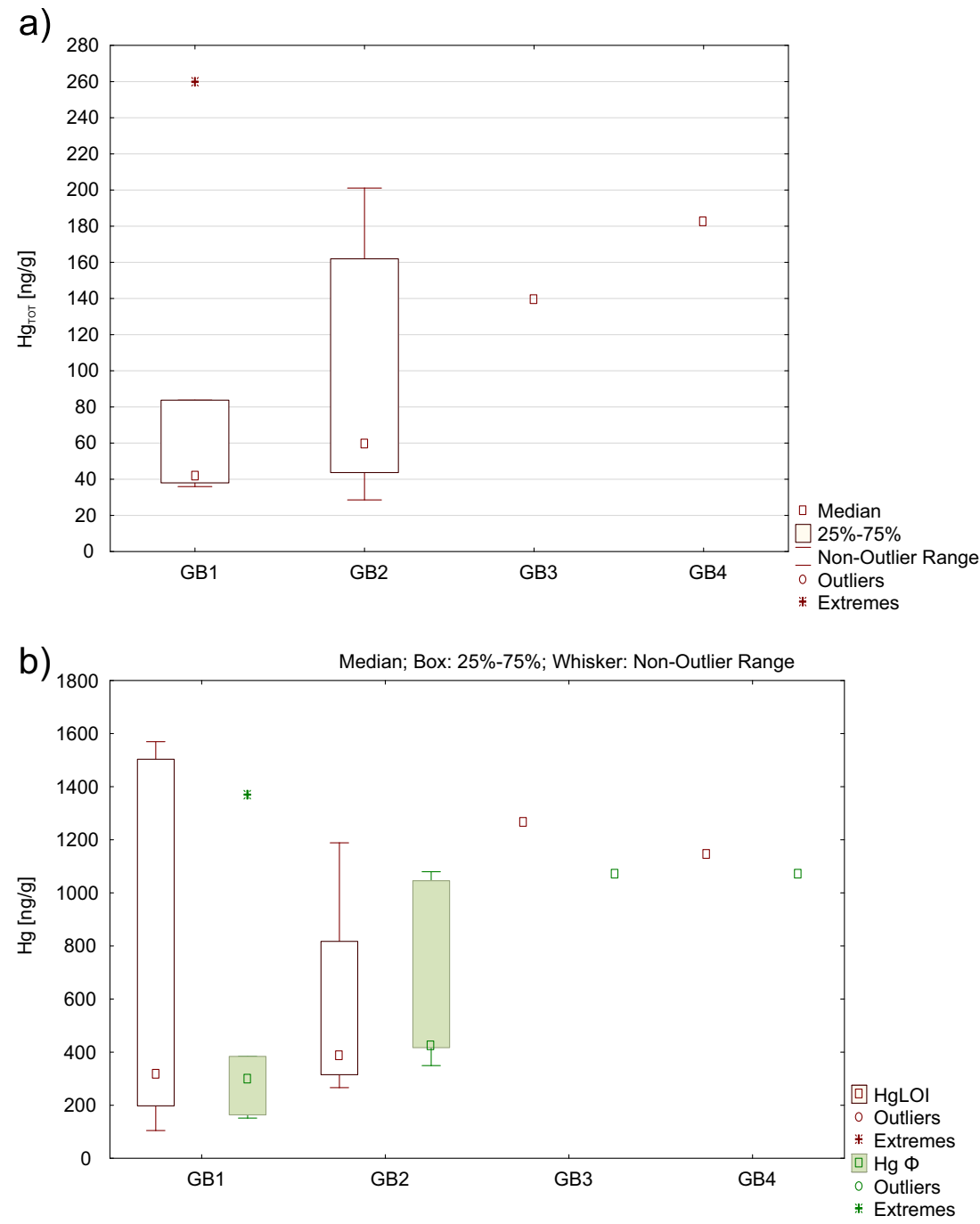
and run-off from the drainage area (HELCOM 2010; Bełdowska et al. 2014).

In the central part of the Gdansk Basin, the surface sediments were sandy-silty in nature, while the proportion of the ultra-fine fraction ranged from 7 to $27 \%$ (mean $17 \%$ ). The wetness of surface sediments in this region ranged from 38 to $90 \%$ (mean $75 \%$ ), while the proportion of organic matter ranged from 3 to $40 \%$ (mean $16 \%$ ).

The highest concentrations of mercury were found in the area of the western incline of the Gdansk Deep (GB4), where polluted sediment flows in from other regions of the Baltic such as the Bay of Pomerania, as indicated by the near-bottom currents coming from the direction of the Stupsk Trough (Piechura et al. 1997; Bełdowski and Pempkowiak 2007).

The concentration of mercury, normalised to organic matter $\left(\mathrm{Hg}_{\mathrm{LOI}}\right)$, was higher than the concentration of mercury normalised to the fine fraction content $(\operatorname{Hg} \varphi)$ at all stations in the open part of the Gulf of Gdansk, a fact which indicates an input of metal bound to organic matter, e.g. of autochthonic origin (Fig. 5b). An exception was a station located in the centre of the Gdansk Deep (GB2), where the concentration of $\mathrm{Hg}_{\mathrm{LOI}}$ was much lower than $\mathrm{Hg} \varphi$. This indicated a large proportion of mercury forms unbound to organic substances. This region is characterised by the relatively slow speed of near-bottom currents (Bełdowski et al. 2009) and, thus, limited sediment resuspension. Taking into account the frequent occurrence of anoxia in this region and long residence time of sediments, the diagenesis of organic matter can occur without interruptions, which leads to both a reduction in the concentration of the labile fractions of organic matter and the formation of mercury sulphide in reductive conditions (Jackson 1998; Bełdowski 2004). The process is not reversible as in the shallower parts of the Gdansk Deep, where oxygen concentration increases and mercury sulphide becomes oxidised to soluble sulphates, and there is also no transportation of labile organic matter from other areas of the Baltic, as on the western incline of the Deep. The highest mercury concentration in the fine-grained fraction and LOI were found at two stations: GB3 (1070 and $1264 \mathrm{ng} \mathrm{g}^{-1} \mathrm{dw}$, respectively) and GB4 (1072 and $1144 \mathrm{ng} \mathrm{g}^{-1} \mathrm{dw}$, respectively). These stations are directly influenced by large rivers: station GB3 is an accumulation place of fine-grained material from the River Vistula, while station GB4 is located en route of seawater flowing in from the North Sea which periodically transports finegrained material from the Bay of Pomerania, originating in the River Oder (Piechura et al. 1997).

\subsection{Temporal variability of mercury concentrations and its inflow into sediments}

The considerable decrease of $\mathrm{Hg}_{\mathrm{TOT}}$ concentrations in the sediments of the Southern Baltic in 1991-2013 was mostly related to the reduced usage and emission of mercury and, as a consequence, a smaller inflow of this metal into the Baltic, a fact which is widely described in HELCOM reports (2004, $2010)$. Consequently, the input of mercury $\left(\Delta \mathrm{Hg}_{\mathrm{TOT}}\right)$ was much smaller at the beginning of the twenty-first century than it had been at the end of the twentieth century. An additional factor influencing the drop in mercury concentrations in the surface layer of sediments is the change in the rate of the sedimentation process and the quality of the material that is introduced to sediments. Lead-210 analyses did not show any significant changes in the rate of accumulation of sediments in the region of the Gdansk Basin (Suplińska and Pietrzak-Flis 2008; Beldowski and Pempkowiak 2009; Szmytkiewicz and Zalewska 2014), while the concentration of organic matter observed in the present paper is similar to the data found in literature in the years 1999-2002 (Bełdowski and Pempkowiak 2003), which testifies to a similar nature of the material introduced to sediments at that time.

In the $1990 \mathrm{~s}, \mathrm{Hg}_{\mathrm{TOT}}$ concentrations in surface sediments in the areas of the Vistula mouth, central Gdansk Basin and Puck Bay remained fairly unchanged (Szczepańska and Uścinowicz 1994; Kannan and Falandysz 1998; Uścinowicz et al. 2011) (Fig. 6). An exception was the deep water region of the Gdansk Basin where the concentration of mercury increased in 1997, following a flood in the River Oder, the second largest river in Poland. That flood, the largest in 50 years, lasted 5 weeks during which the Baltic received a volume of water equivalent to $50 \%$ of the mean annual Oder discharge, while the average flow of the river at that time was more than six times greater than normal (Siegel et al. 1999). The flood water introduced to the Bay of Pomerania a mercury load that was five times higher than the values measured at other times (Pohl et al. 2002). The solution, enriched with mercury, could have been transported eastwards in the direction of the Slupsk Trough and further to the region of the western incline of the Gdansk Deep, aided by the near-bottom currents in that area (Piechura et al. 1997; Bełdowski and Pempkowiak 2007). Increased sedimentation of the polluted material in the area of station GD4 was reflected by the volume of the gross mercury input to the sediments $\left(\Delta \mathrm{Hg}_{\mathrm{TOT}}\right)$ (Fig. 6). The mean values calculated for the period 1994-1997 for that area were twice as high as during 1991-1993 (Fig. 6). The significant influence of a flood and, consequently, of the increased load of mercury introduced into the basin on a rise in its input to surface sediments was also observed in the central part of the Gdansk Basin and the Vistula River mouth following a Vistula flood (Saniewska et al. 2014). Extreme rainfall lasting nearly a month had led to many pollutants being washed off the land (e.g. landfills, cemeteries and septic tanks) and transported into the Baltic Sea. The time of the Vistula flood was characterised by a river flow that was three times greater than at other times. As a result, the inflow of mercury in 2010 in the Vistula River mouth area increased nearly 20 times. Subsequent, less extreme but nevertheless intense rainfall 

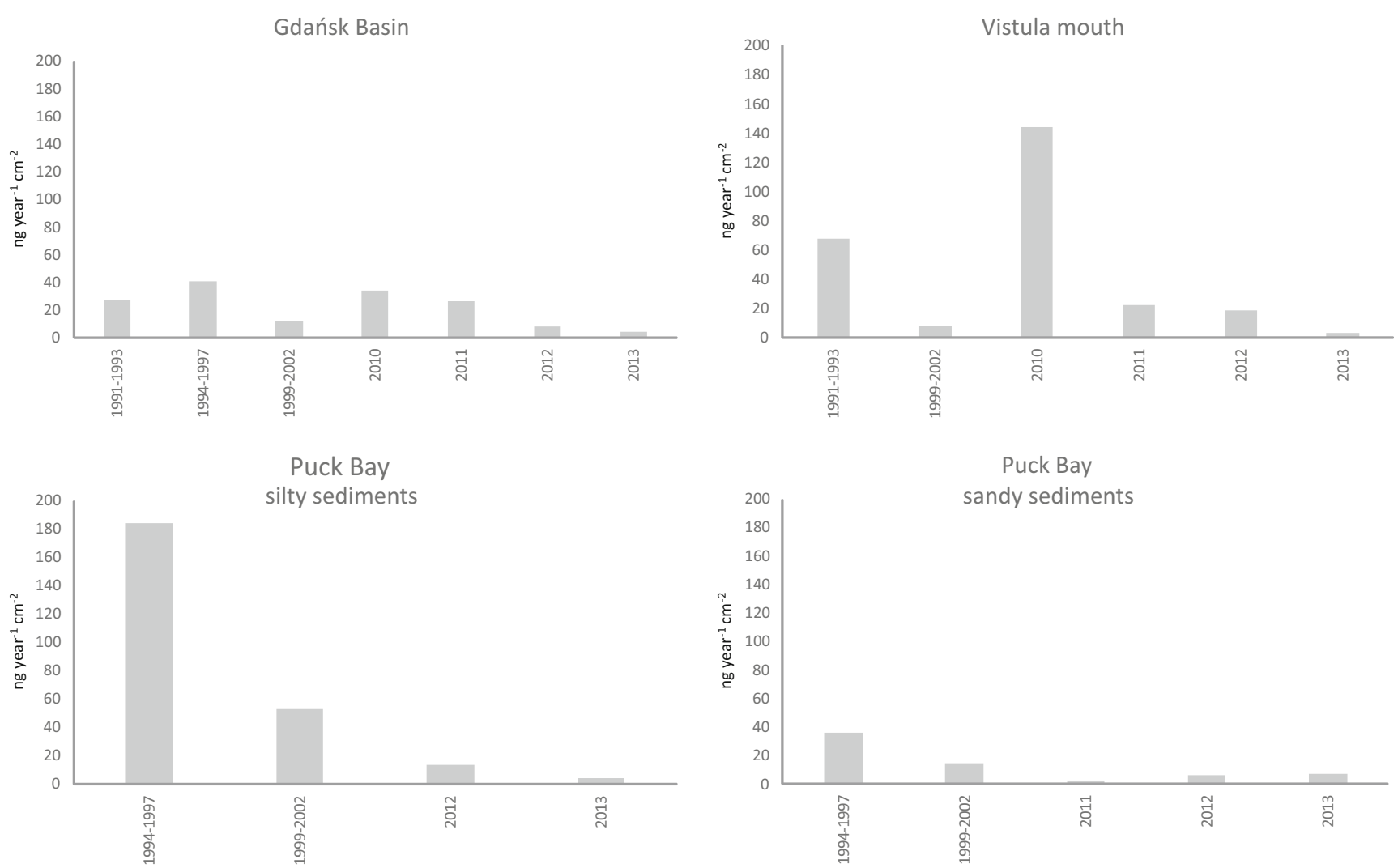

Fig. 6 Mercury deposition in the study area (ng m ${ }^{-2}$ day $^{-1}$ ) in 1991-1993 (Szczepańska and Uścinowicz 1994), 1994-1997 (Boszke 1999; Uścinowicz et al. 2011), 1992-2002 (Bełdowski and Pempkowiak 2007); 2010 (Bełdowski et al. 2014) and 2011-2013 (this study)

influenced the mobilisation of the suspension deposited during the flood in the river trough, which resulted in increased mercury deposition persisting during 2011 and 2012 (Fig. 6). Increased deposition was observed not only in the area of station VW but also in the central part of the Gdansk Basin. In that region, $\Delta \mathrm{Hg}_{\text {Tот }}$ was similar in 2010 and 2011, probably due to suspension from the coastal zone having been transported to an area of quiet sedimentation, which in the Baltic takes place as a cycle of sedimentation and resuspension (Pempkowiak et al. 2002; Christiansen et al. 2002). The transportation of fine-grained sediment suspension from the shallow, high-energy areas in the coastal zone to sedimentation basins may take from a few months to more than a year and leads to raised metal concentrations in seabed sediments en route of such transportation (Pempkowiak et al. 2002).

The Puck Bay, owing to its high current velocities (Zajaczkowski et al. 2010), does not accumulate pollutants introduced via the Vistula River, which is why no distinct influence of the 2010 flood was observed there. In the 20112013 study period, the inflow of mercury remained fairly stable. The slight increase of $\Delta \mathrm{Hg}_{\mathrm{TOT}}$ to sandy sediments of the bay observed in 2012-2013, compared to 2011, was probably caused by the fact that, unlike in 2011 , the bay was covered with ice in the winter season of 2012 and 2013. In winter, the stream of mercury bound to atmospheric precipitation is distinctly higher than in summer, due to emission from fossil fuel combustion (Bełdowska et al. 2012). The icing close to the shore and watercourse outlets limited the transportation of the suspension from land into the bay during winter, while during melting the mercury from the land was distributed mainly close to the outlets. This led to mercury concentrations increasing locally in sandy sediments of the coastal zone (PB1-PB7). No such tendency was observed in the area of station PB8, as the run-off does not easily reach this region (no river outlets or small strip of land). Here, the raised deposition in 2012 could have been caused by the remobilisation of mercury, which became deposited in shallower regions of the Gulf of Gdansk, as this area is covered in silty sediments, indicating undisturbed sedimentation.

\section{Conclusions}

Temporal trends prove that even in a relatively short time period (i.e. years), a relatively high variability of mercury concentrations in surface sediments can occur, both in the coastal area and offshore. The thickness of the studied sediment layer was $5 \mathrm{~cm}$, which corresponds to 7 to 31 years of deposition, depending on the area. Observed inter-annual changes suggest that sediment mixing, remobilisation of mercury and complicated sedimentation/resuspension cycles, 
common in coastal waters, make it difficult to characterise the overall mercury concentration for a given area based on contemporary measurements. Moreover, the observed differences do not follow a systematic trend, which could be attributed to emission history. Although some decreasing trend of mercury concentration in surface sediments could be deduced, the data contain a lot of noise and determination coefficients are not very high (0.16 to 0.59$)$, with the exception of the silty area of Puck Bay (0.89), which may result from a shorter data series. The noise observed in the temporal trend, especially in coastal areas, results most probably from climate-related parameters, such as extreme events and the magnitude of icing, as well as the remobilisation and transport of mercury between different areas. It follows from observations that in the present situation, when mercury emission has been successfully inhibited, concentrations of this metal in sediments reflect natural metal migration processes rather than the direct influence of anthropogenic sources.

The above observations are of considerable importance as climate changes in the study regions are progressing towards ever warmer winters which will, in turn, lead to the shortening of the duration and surface area of icing on the bay. Furthermore, forecasts of climate change predict more frequent downpours of rain that will lead to floods and periodic inundations.

Acknowledgments This study has been performed within the framework of a National Science Centre project: No. 2011/01/B/ST10/07697.

Open Access This article is distributed under the terms of the Creative Commons Attribution 4.0 International License (http:// creativecommons.org/licenses/by/4.0/), which permits unrestricted use, distribution, and reproduction in any medium, provided you give appropriate credit to the original author(s) and the source, provide a link to the Creative Commons license, and indicate if changes were made.

\section{References}

Bełdowska M, Saniewska D, Falkowska L, Lewandowska A (2012) Mercury in particulate matter over Polish zone of the southern Baltic Sea. Atmos Environ 46:397-404

Bełdowska M, Saniewska D, Falkowska L (2014) Factors influencing variability of mercury input to the southern Baltic Sea. Mar Pollut Bull 86:283-290

Bełdowska M, Zawalich K, Falkowska L, Siudek P, Magulski R (2008) Total gaseous mercury in the area of southern Baltic and in the coastal zone of the Gulf Of Gdansk, during spring and autumn. Environ Prot Eng 4:139-144

Bełdowski J (2004) Factors affecting of mercury concentration and speciation and their meaning in bottom sediments of western Gdańsk Basin. PhD Thesis, University of Gdańsk, Poland

Beldowski J, Pempkowiak J (2009) Mercury concentration and solid phase speciation changes in the course of early diagenesis in marine coastal sediments (Southern Baltic Sea). Mar Freshw Res 60:745757
Bełdowski J, Pempkowiak J (2003) Horizontal and vertical variabilities of mercury concentration and speciation in sediments of the Gdansk Basin, Southern Baltic Sea. Chemosphere 52:645-654

Bełdowski J, Pempkowiak J (2007) Mercury transformations in marine coastal sediments as derived from mercury concentration and speciation changes along source/sink transport pathway (Southern Baltic). Estuar Coast Shelf Sci 72:370-378

Bełdowski J, Miotk M, Pempkowiak J (2009) Mercury fluxes through the sediment water interface and bioavailability of mercury in southern Baltic Sea sediments. Oceanologia 51:263-285

Bełdowski J, Miotk M, Bełdowska M, Pempkowiak J (2014) Total, meth$\mathrm{yl}$ and organic mercury in sediments of the Southern Baltic Sea. Mar Pollut Bull 87:388-395

Boening DW (2000) Ecological effects, transport, and fate of mercury: a general review. Chemosphere 40:1335-1351

Boszke L (1999) Mercury in the Puck Bay Ecosystem: concentrations in biotic and abiotic components, spatial variability, source estimation history of pollution and balance. PhD Thesis, University of Gdańsk, Poland

Christiansen C, Edelvang K, Emeis K, Graf G, Jahmlich S, Kozuch J, Laima M, Leipe T, Loffler A, Lund-Hansen LC, Miltner A, Pazdro K, Pempkowiak J, Shimmield G, Smith J, Smith J, Voss M, Witt G (2002) Material transport from the nearshore to the basinal environment in the southern Baltic Sea-I. Processes and mass estimates. J Mar Syst 35:133-150

Ciborowski T (2010) Organic substances. In: Bolałek J (ed) Physical, biological and chemical studies of marine sediments. University of Gdańsk Press, Gdańsk, pp 287-290

Cyberski J (1993) Hydrology of catchment. In: Korzeniewski K (ed) The Puck Bay. Institute of Oceanography, University of Gdańsk, Gdańsk, pp 40-71

Damrat M, Zaborska A, Zajączkowski M (2013) Sedimentation of suspended matter versus accumulation of sediments in River Vistula mouth. Conference Proceedings "Geological processes in the coastal zone of the sea”, Gdynia, Poland, pp 22-23

Daskalakis KD, O'Connor TP (1995) Normalization and elemental sediment concentration in the coastal United States. Environ Sci Technol 29:470-477

Emeis K, Christiansen C, Edelvang K, Jahmlich S, Kozuch J, Laima M, Leipe T, Loffler A, Lund-Hansen LC, Miltner A, Pazdro K, Pempkowiak J, Pollehne F, Shimmield T, Voss M, Witt G (2002) Material transport from the near shore to the basinal environment in the southern Baltic Sea-II: synthesis of data on origin and properties of material. J Mar Syst 35:151-168

Fitzgerald WF, Lamborg CH (2003) Geochemistry of mercury in the environment. In: Holland HD, Turekian KK (eds) Treatise on geochemistry, vol 9, Chp 4, vol 9. Elsevier, Amsterdam, pp 1-38, ISBN 0-08-043751-6

GUS (2014) Pomorskie in figures 2014. In: Office MS (ed) Statistical Office in Gdańsk, Olsztyn, Poland, 24 pp

HELCOM (2004) The Fourth Baltic Sea Pollution Load Compilation (PLC-4). Baltic Sea Environ Proc No 93. Helsinki Commission, Helsinki, Finland, 188 pp

HELCOM (2010) Hazardous substances in the Baltic Sea - an integrated thematic assessment of hazardous substances in the Baltic Sea. Baltic Sea Environ Proc No 120B. Helsinki Commission, Helsinki, Finland, 116 pp

Hortellani MA, Sarkis JES, Bonetti J, Bonetti C (2005) Evaluation of mercury contamination in sediments from Santos - Sao Vicente Estuarine System, Sao Paulo State, Brazil. J Braz Chem Soc 16:1140-1149

Jackson TA (1998) Mercury in aquatic ecosystem. In: Langston J, Bebino MJ (eds) Metal metabolism in aquatic environment. Chapman \& Hall, London, pp 178-249

Jankowska H, Łęczyński L (1993) Bottom sediments. In: Korzeniewski K (ed) The Puck Bay. Institute of Oceanography University of Gdańsk, Gdańsk, Poland, pp 320-327 
Kannan K, Falandysz J (1998) Speciation and concentration of mercury in certain coastal marine sediments. Water Air Soil Pollut 103:129-136

Lafabrie C, Major KM, Major CS, Miller MM, Cebrian J (2011) Comparison of morphology and photo-physiology with metal/ metalloid contamination in Vallisneria neotropicalis. J Hazard Mater 191:356-365

Majewski A (1990) Morfometria i hydrografia zlewiska. In: Majewski A (ed) Zatoka Gdańska. Wydawnictwa Geologiczne, Warsaw, Poland, pp 10-19

Pempkowiak J (1997) Basics of marine geochemistry. Wydawnictwo Uniwersytetu Gdańskiego, Gdańsk, Poland, 171 pp

Pempkowiak J, Cossa D, Sikora A, Sanjuan J (1998) Mercury in water and sediments of the southern Baltic Sea. Sci Total Environ 213: 185-192

Pempkowiak J, Bełdowski J, Pazdro K, Staniszewski A, Leipe T, Emeis KE (2002) The contribution of the fine sediment fraction to the Fluffy Layer Suspended Matter (FLSM). Oceanologia 44:513-527

Piechura J, Walczowski W, Beszczyńska-Möller A (1997) On the structure and dynamics of the water in the Słupsk Furrow. Oceanologia $39: 35-54$

Pohl C, Hennings U, Siegel H, Bachor A (2002) Trace metal impact into the Baltic Sea during the exceptional Oder flood in summer 1997. Mar Chem 79:101-111

Saniewska D, Bełdowska M, Bełdowski J, Saniewski M, Kwaśniak J, Falkowska L (2010) Distribution of mercury in different environmental compartments in the aquatic system of the coastal zone of Southern Baltic Sea. J Environ Sci 22:1144-1150

Saniewska D, Bełdowska M, Bełdowski J, Jędruch A, Saniewski M, Falkowska L (2014) Mercury loads into the sea associated with extreme flood. Environ Pollut 191:93-100
Siegel H, Gerth M, Mutzke A (1999) Dynamics of the Oder river plume in the Southern Baltic Sea: satellite data and numerical modelling. Cont Shelf Res 19:1143-1159

Suplińska MM, Pietrzak-Flis Z (2008) Sedimentation rates and dating of bottom sediments in the Southern Baltic Sea region. Nukleonika 53: $105-111$

Szczepańska T, Uścinowicz S (1994) Geochemical atlas of the Southern Baltic 1:500 000. Polish Geological Survey, Warsaw, Poland

Szmytkiewicz A, Zalewska T (2014) Sediment deposition and accumulation rates determined by sediment trap and ${ }^{210} \mathrm{~Pb}$ isotope methods in the Outer Puck Bay (Baltic Sea). Oceanologia 56:85-106

Udden JA (1914) Mechanical composition of clastic sediments. Bull Geol Soc Am 25:655-744

Uścinowicz S, Szefer P, Sokołowski K (2011) Trace elements in Baltic Sea sediments. In: Uścinowicz S (ed) Geochemistry of surface sediments of the Baltic Sea. Polish Geological Survey, Warsaw, Poland, pp 214-274

Wallschläger D, Desai MVM, Spengler M, Windmöller CC, Wilken RD (1998) How humic substances dominate mercury geochemistry in contaminated floodplain soils and sediments. J Environ Qual 27: 1044-1054

Wentworth CK (1922) A scale of grade and class terms for clastic sediments. J Geol 30:377-392

WHO (1990) Methylmercury (Environmental Health Criteria No. 101). World Health Organization, Geneva, Switzerland, 144 pp

Zajaczkowski M, Darecki M, Szczucinski W (2010) Report on the development of the Vistula river plume in the coastal waters of the Gulf of Gdansk during the May 2010 flood. Oceanologia 52:311-317 